\title{
Claudio Cataldi*
}

\section{The Alfrician Glossaries in Oxford, Bodleian Library, Barlow 35: A New Edition and Commentary}

https://doi.org/10.1515/ang-2020-0020

\begin{abstract}
The present study provides a full edition and commentary of the three glossaries in Oxford, Bodleian Library, Barlow 35, fol. 57r-v. These glossaries, which were first partly edited and discussed by Liebermann (1894), are comprised of excerpts from Ælfric's Grammar and Glossary arranged by subject. The selection of material from the two Ælfrician works witnesses to the interests of the glossator. The first glossary in Barlow 35 collects Latin grammatical terms and verbs followed by their Old English equivalents. The second glossary is drawn from the chapter on plant names of Ælfric's Glossary, with interpolations from other chapters of the same work. This glossary also features twelfth-century interlinear notations, which seem to have a metatextual function. The third glossary combines excerpts from Ælfric's Glossary with verbs derived from the Grammar. Liebermann transcribed only part of the glosses and gave a brief commentary on the glossaries as well as parallels with Zupitza's (1880) edition of Ælfric's Grammar and Glossary; hence the need for a new edition, which is provided in the present study, along with a comprehensive discussion of the glossaries and a reassessment of the correspondences concerning their Ælfrician sources.
\end{abstract}

\section{Introduction}

Oxford, Bodleian Library, Barlow 35 preserves three Latin-Old English glossaries on fol. $57 \mathrm{r}-\mathrm{v}$, which were first discussed and partly edited by Felix Liebermann (1894). As noted by previous scholarship, the sources of these glossaries are Ælfric’s Grammar and Glossary (Ker 1957: no. 298; Buckalew 1978: 154; Lendinara 1999: 13, 214). Taken in their entirety, the three glossaries in Barlow 35 include 147 entries organized by subject.

The first glossary, on fol. 57r, includes 40 entries and is set out in three columns. Most interpretamenta are written on the line below their respective 
lemmata, but in the second column (E) some entries feature both lemma and explanation on the same line (see Figure 1). This first glossary draws grammatical terms and explanations of verbs from Ælfric's Grammar, reworking them into word-pairs. Verbs are mostly taken from the chapter on the Latin third conjugation (ed. Zupitza 1880: 162-182).

The second glossary is much more extended; it is written on the upper half of fol. $57 \mathrm{v}$ and features 70 entries, with lemmata and interpretamenta written continuously (see Figure 2). This second glossary mostly overlaps with the chapter on plant names in Ælfric’s Glossary (ed. Zupitza 1880: 310-311), with a few interpolations from other chapters. Several entries also feature twelfth-century additions; a later scribe copied interlineally the initial letters of a number of lemmata (see Figure 2, fol. 57v/1-19). The reason for these interlinear additions is unclear, but I believe that they might have had a metatextual function, which I shall discuss below (p. 224).

The third glossary is copied on the bottom half of fol. $57 \mathrm{v}$; set out in six columns, it includes 35 glosses; interpretamenta are written mostly below their respective lemmata (see Figure 2). This third glossary has two main parts; the first section is drawn from Ælfric's Glossary, while the second section is comprised of Latin second-conjugation verbs taken from Ælfric's Grammar (ed. Zupitza 1880: 147-158). As in the first glossary, these excerpts from the Grammar are organized in word-pairs. The material in the third glossary - and, to a lesser extent, in the first glossary - suggests that the compiler selected the verbs on the basis of their Latin conjugation.

To the three glossaries, one must add one other gloss, testu : crocsceard, which is copied on folio 6r and is taken from Ælfric's Grammar (cf. ed. Zupitza 1880: 80.11 testu : crocscerd). ${ }^{1}$ In order to provide a comprehensive study of the three glossaries, I shall first introduce the manuscript (Section 2); sources and analogues of the glossaries will be then discussed in Section 3; finally, a new edition and commentary of the three glossaries is offered in Section 4 (pp. 217-227).

\section{The Manuscript: Barlow 35}

Oxford, Bodleian Library, Barlow 35 is a composite codex, comprised of four booklets in nine quires, dated to the tenth century. There is some disagreement amongst scholars about the origin of the manuscript. The prevalent view is that Barlow 35 is of continental origin and arrived in England by the end of the tenth

1 Cf. Ker (1957: 356) and Doane (2007: 80). 
century; the English additions to the codex date to the late tenth and early eleventh centuries (cf. Ker 1957: 355-356; Doane 2007: 75; Gneuss and Lapidge 2014: no. 541). However, according to the Bodleian Summary Catalogue, the codex is "made up of four MSS. written in the 10th and 11th centt., probably in England", and booklets "A, B, C are in Caroline minuscule showing insular traits" (Madan, Craster, and Denholm-Young 1937: no. 6467). Bischoff (1997: XCVII 2.2.) considered fols. 1-5 of possible English origin ("in Engl[and] geschr[ieben]?") and the rest later (than the tenth century) and written in England ("d[er] Rest jünger, in England geschr[ieben]"). ${ }^{2}$

Part A (fols. 1-5) includes calendarial rules, a version of the Revelatio Esdrae, and a fragment of part of a multiplication table (Doane 2007: 78; Liuzza 2010: 48); scribbles and drawings were added to the first folio, which was originally blank. Part B (fols. 6-43) preserves a copy of Alcuin's Interrogationes Sigewulfi in Genesin. Part C (fols. 44-54) features an enlarged version of the Scholica graecarum glossarum (on which see Lendinara 2011), with a coda of entries drawn from Bede's De orthographia (Lendinara 1999: 293), followed by a note on 'vesper' from Isidore's De natura rerum (see Alcamesi 2010: 180). A Latin charm with heading in Old English was added on fol. 54v (Pettit 1999). In Part D (fols. 55-57), there is a version apparently the only one attested to in Anglo-Saxon England - of pseudo-Cicero's Synonyma and the three Elfrician glossaries that are discussed in this study. The lists of pseudo-Ciceronian synonyms are set out in six columns (with the exception of the preface), on fols. 56rv-fol. 57, cols. 1-3 and col. 4, line 11. On the fourth column of fol. 57r, line 12, the first Ælfrician glossary begins, without either a break from the preceding work or a rubric; it ends on fol. $57 \mathrm{r}$, line 26 . The second Ælfrician glossary is written across the page on fol. $57 \mathrm{v}$, lines $1-19$. The third glossary is set out in six columns on fol. 57v, lines 20-31. The Synonyma and the glossaries are copied in different ink. The two works share the interest in lists of verbs: in the Synonyma, these are organized in groups of synonyms, while the first and the third Ælfrician glossaries collect Latin words followed by equivalents in the vernacular. The first glossary, in particular, is wholly based on grammatical material and preserves a batch of verbs with Old English equivalents; as such, it must have been considered as a proper continuation to the Synonyma by the compiler of Part D. Stokes (2014: 208) notes three English hands on the manuscript: one for the charm and the Ælfrician glossaries and two for the scribbles (cf. Ker 1957: 355-356).

2 See <http://www.mgh-bibliothek.de/cgi-bin/digilib.pl?img=38\&ident=h001460_47\&dir $=$ h\&tit $=>$. 


\section{Sources and Analogues of the Glossaries in Barlow 35}

The three Latin-Old English glossaries in Barlow 35 can be classified as class glossaries; they are organized by subject and derive part of their material from Ælfric's Glossary. Flfric composed his three educational works, the Grammar, the Glossary, and the Colloquy between 992 and 1002 (Hill 2007: 285); Kleist (2019: 127-129) narrows the temporal range to 993-998. The Grammar, the Glossary, and the Colloquy enjoyed a wide circulation, and the three glossaries in Barlow 35 are one of the offshoots of this tradition. Ælfric's Grammar (henceforth: ÆGr) and the Glossary (henceforth: ÆGl) are transmitted together in six medieval codices; in all manuscripts, the ÆGl immediately follows the ÆGr (Buckalew 1978: 153-155; Gneuss and Lapidge 2014: nos. 13, 115, 331, 336, 414, 686). Considered the first Latin grammar in any European vernacular language, ${ }^{3} Æ G r$ is organized in sections aimed to explain the Latin alphabet, syllables, diphthongs, parts of speech, genders, declensions, number; discussions of each verbal conjugation are followed by a separate chapter on passive forms; discrete chapters are also devoted to anomalous, defective, inchoative, and frequentative verbs. ÆGl is arranged in eight chapters organized by subject; an introductory chapter is followed by the sections Nomina membrorum ('Names of members' - parts of the body, members of the family, of the society, etc.); Nomina auium ('Names of birds'); Nomina piscium ('Names of fish'); Nomina ferarum ('Names of animals'); Nomina herbarum ('Names of herbs'); Nomina arborum ('Names of trees'); Nomina domorum ('Names of houses'). ÆGl shares the chapter-format with other Latin-Old English class glossaries such as the Antwerp-London class glossary, the Second Cleopatra Glossary, and the Brussels Glossary. ${ }^{4}$ Furthermore, it is worth noting that ÆGl and Antwerp-London presumably rely on the same sources (see Lazzari 2003; Porter 2011b; Porter 2018). ÆGr and ÆGl were copied and used well after the Anglo-Saxon period (see Hill 2007). A copy of the two works is preserved in Worcester, Cathedral Library, F.174, a thirteenthcentury codex copied by the well-known 'Tremulous Hand of Worcester' (this version is edited by Butler 1981). The fourth of a group of four glossaries preserved in Oxford, Bodleian Library, Bodley 730, which dates back to the early thirteenth century, is mostly based on the chapter Nomina membrorum of $Æ G l$, along with other material not derived from Ælfric (see Cataldi 2019). Both this glossary in Bodley 730

3 On the sources and aims of ÆGr, see Gneuss (1990); Menzer (2004).

4 For an overview of Latin-Old English class glossaries, see Lendinara (2009). Edition of the Antwerp-London class glossary in Porter (2011a); editions of the Second Cleopatra Glossary and of the Brussels Glossary in Rusche (1996). 
and the glossarial material in Barlow 35 re-use material from ÆGl. In terms of these parallels, one might add the copies of $Æ G r$ in the manuscripts London, British Library, Cotton Faustina A.x and Cambridge, University Library, Hh.1.10, which feature glosses and annotations in Latin, Anglo-Norman, and English from the second half of the eleventh century to the twelfth century (see Hunt 1991: I, 99-113; Pagan and Seiler 2019). The glossaries in Barlow 35 may therefore represent early instances of use and re-use of $Æ G r$ and $Æ G l$, re-uses which are well documented up into the Early Middle English period.

\section{Edition and Commentary of the Alfrician Glossaries in Barlow 35}

Below I offer a full edition with commentary of the three glossaries in MS Barlow 35. Comparisons with ÆGr and ÆGl are provided, with page and line numbers referring to Zupitza (1880), who used Oxford, St John's College, 154 (manuscript ' $O$ ') as his base text. Because all of the three glossaries derive material from the same source, glosses are numbered consecutively. Latin lemmata are capitalized in this, I follow a consistent practice found in Barlow 35 - and all English interpretamenta are printed in small letters, including a number of occurrences that are capitalized in the manuscript. I keep the punctus that, in the manuscript, separates lemmata from interpretamenta; abbreviations are expanded and shown by italics, except $t$ for $u e l$, which is retained. Emendations are in square brackets. Word division has been regularised without notice.

\subsection{Glossary I (see Figure 1)}

Barlow 35, fol. 57r, cols. D-F

D 1 Signifer . tacenberend.

2 Simplex. ánfeald.

3 Composita . gefeged.

4 Optauimus . gewyscent .
Parallels in $\mathbb{A G r}$ and $\boldsymbol{A E G I}$

(ed. Zupitza 1880)

AEGr 27.15 signifer tacnberend; AEGI 317.20 signifer tacnbora

AEGr 70.1 simplex anfeald; similarly 87.8-9; 91.13; 105.21; 223.13

AEGr 87.9 ет сомPosita pæt is, gefeged; similarly 91.13-14; 105.21-106.1; 217.12

AEGr 125.9-10 optativvs pæt is, gewiscendlic 


\section{Barlow 35, fol. 57r, cols. D-F}

5 Vtinam . eala .

6 Amare uolo. ic wille lufian.

7 Amabis . pu lufast .

E 8 Eodem modo on pam ylcan gemete.

9 Amaueritis . pa da ge lufedan .

10 Consolor . ic gefrefrige .

11 Gratulor . ic blissige .

12 Coniunctio . gepodnys.

13 Significatio . getácnuncg .

14 Commoda mihi III panes lǽn me preo hlafas.

15 Sagene. sǽnét.

16 Cunabulum . cidcradel .

17 Cupio ic gewilnige .

18 Acuo . ic hwette.

19 Sumo . ic underfo.

20 Ambigo . me twynad.

21 Detraho . ic tele.

22 Cogo . ic nyde.

23 Ácuo . íc hẃette.

24 Vinco . ic oferswiðe.

25 Confundo. ic gemencge .

26 Como . ic geglencge .

27 Tempno . ic forseo .

\section{Parallels in $\boldsymbol{A E G r}$ and $\boldsymbol{A E G I}$}

(ed. Zupitza 1880)

AEGr 125.12, 14-15, 16-17; 131.19-21;

132.1-9; 141.6-19; 142.1-6; 149.1-9;

200.3-4; 208.18; 209.1; 227.13 utinam [...]

eala

AEGr 126.11 amare uolo ic wylle lufjan; similarly $134.7-8$

ÆEGr 131.7 amabis pu lufast

AEGr 130.10-11 EOdem modo [...] on dam ylcan gemete; similarly 131.5

AEGr 133.17-134.1 amaueritis ðonne ge lufjað gyt; cf. AEGr 133.12-13 amauissetis pa ða ge lufedon

AEGr 145.3 consolor ic gefrefrige

AEGr 145.14-15 gratulor ic blissige

ÆEGr 257.16-258.1 conIUnctio mæg beon gecweden gepeodnys

AEGr 119.12-13 SIGNIFICATIO, pæt ys, getacnung; similarly 223.16; 242.17 ; 278.4-5

AEGr 135.7-8 commoda mihi librum ad legendum læne me ða boc to rædenne AEGI 320.14 sagena sænett AEGr 85.9-10 cunabula cildecradulas AEGr 166.4, 166.10 cupio ic gewilnige AEGr 167.1 acuo ic hwette AEGr 169.15 sumo ic underfo AEGr 176.13 ambigo me twynad AEGr 176.7 detraho ic tæle bæftan AEGr 176.12-13 cogo ic nyde AEGr 167.1 acuo ic hwette AEGr 176.18 uinco ic oferswiðe AEGr 178.8-9 confundo ic gemencge oðde gescynde

AEGr 170.1 como ic geglencge

AEGr 170.6 tempno ic forseo 
Barlow 35, fol. 57r, cols. D-F

F 28 Studeo . ic gecnyrdlæce.

29 Floreo . ic blowe .

30 Vigeo . ic strangige .

31 Zelor . ic andige.

32 Lippus. sureagede.

33 Consuesco ic gewunige .

34 Comprimo . ic ofpricce.

35 Claudo . ic beluce.

36 Succido. ic ceorfe.

37 Extinguo ic acwence.

38 Construo . ic timbrige.

39 Consequor . ic begyte.

40 Sisto . ic sette.
Parallels in $\boldsymbol{A E G r}$ and $\boldsymbol{A E G I}$

(ed. Zupitza 1880)

AEGr 154.5 studeo ic gecnyrdlæce

AEGr 154.9 floreo ic blowe

AEGr 154.14 uigeo ic strangige oððе geðеo

AEGr 146.8 zelor ic andige

AEGr 192.10-11 lippus sureagede

AEGr 165.8 consuesco ic gewunige

AEGr 170.4 comprimo ic samod ofərycce

ÆEGr 171.4 claudo ic beluce

AEGr 172.3 succido ic forceorfe

AEGr 174.4-5 extinguo ic acwence

AEGr 175.11 struo and construo ic timbrige

AEGr 186.3-4 consequor ic begyte

AEGr 203.8 sisto ic sette

\section{Notes on Glossary I}

The first glossary features glossae collectae from $Æ G r$ (plus one entry from $Æ G l$ ) organized to build a collection of grammatical terms, which includes definitions of the parts of speech (for example 12 Coniunctio : gepodnys 'junction'), adjectives (for example 2 Simplex : ánfeald 'uncompounded', 3 Composita : gefeged 'compounded'), nouns (15 Sagene : sǽnét 'fishing net'; 16 Cunabulum : cidcradel 'cradle'), and especially verbs, all equipped with Old English equivalents (which are also derived from $Æ G r$ and $Æ G l)$. Several entries have more than one occurrence.

1 Signifer : tacenberend 'standard-bearer' (see BT s.v. tacn-berend) not only corresponds to the passage of ÆGr noted by Liebermann, but also parallels ÆGl 317.20.

4 Optauimus stands for optatiuus 'optative'.

5 Vtinam and eala are always employed within brief sentences in ÆGr; the entry Vtinam : eala 'o that!' in Glossary I is a good example of how the compiler reworked the material from $Æ G r$ into word-pairs.

6-7, 9 Three glosses related to the verb amare 'to love'. 9 Amaueritis : pa ða ge lufedan shows that the glossator confused amaueritis 'you [pl.] would love' (or 
'you [pl.] will have loved', if intended as a future perfect) with amauissetis 'you [pl.] would have loved'.

12 Coniunctio : gepodnys ‘junction’ parallels ÆGr 257.16-258.1 rather than the passage indicated by Liebermann (ÆGr 129.15), which refers to coniugatio uerborum 'conjugation of verbs' and not coniunctio 'conjunction'. This is another instance that shows that the compiler reworked the Ælfrician material into word-pairs.

14 Commoda mihi III panes : læn me preo hlafas 'lend me three loaves’ is presumably drawn from ÆGr 135.7-8 commoda mihi librum ad legendum : læne me ða boc to rædenne 'lend me the book to read'; however, the entry is somewhat shorter than its source and also differs in the noun used as example (boc 'book', instead of hlafas 'loaves'). Liebermann (1894: 414 n. 5) convincingly proposes a reference to Luke xi.5, which perhaps influenced the adaptation of $Æ G r$ 135.7-8 into this gloss.

15-16 Lemmata 15 and 16 are written on the same line [= 57r/E15], with the interpretamenta on the line below. Cidcradel stands for cildcradel 'child's cradle'.

17-40 A group of first-person singular indicative present verbs, which were glossed by the corresponding vernacular verb form introduced by the personal pronoun ic. This batch of verbs was mostly excerpted from the chapter on the Latin third conjugation of $Æ G r$, but with some interpolations: second-conjugation verbs (glosses 28-30: Studeo : ic gecnyrdlæce 'I study', Floreo : ic blowe 'I flourish', Vigeo : ic strangige 'I grow strong'); first-passive conjugation (31 Zelor : ic andige 'I envy [sb./sth.]'). A further two first-passive conjugation verbs are found earlier in the glossary: 10 Consolor : ic gefrefrige 'I comfort [sb.]'; 11 Gratulor : ic blissige 'I rejoice'. However, it is worth noting that the compiler also included a third-passive conjugation verb (gloss 39 Consequor : ic begyte 'I pursue [sb./sth.]'); and a defective third-conjugation verb (40 Sisto : ic sette 'I set, place [sth.]'). The latter is derived from a section of $Æ G r$ which is different from the one that served as a source for the other verbs. This suggests that the glossator deliberately selected this verb because its conjugation agrees with the other third-conjugation verbs. Furthermore, in cases where $Æ G r$ has more than one vernacular equivalent, the glossator chose only one interpretamentum, as in 30 Vigeo : ic strangige 'I grow strong' and 25 Confundo : ic gemencge 'I mingle [sth]'.

23 Ácuo : íc hẃette 'I whet [sth.]' doubles gloss 18. In this second instance, the glossator included accent marks; moreover, the interpretamentum is written vertically in what seems to be a different ink. It is possible that the scribe mistakenly copied acuo twice and added the interpretamentum only when revising the text. 
32 Lippus : sureagede 'blear-eyed' (see BT s.v. sureagede) is the only adjective of this section; it is drawn from $Æ G r ' s$ chapter on fourth-conjugation Latin verbs.

35 Comprimo : ic ofpricce 'I press [sth.]' is another instance in which the glossator built a word-pair, this time by omitting samod 'together'.

\subsection{Glossary II (see Figure 2)}

Barlow 35, fol. 57v/1-19

41 Herba græs oððe wyrt .

42 Allium . leac.

43 Dilla. docca.

44 Lubestica . lufestie .

45 Febrefug[ia] . feferfugiæ .

46 Simfoniaca. hennebelle

47 Auadonia . feltwyrt.

48 Aprotanum superne wudu.

49 Sinittia . grundswelige.

50 Feniculum , finol.

51 Anetum . dile.

52 Electrum . elehtre.

53 Malua. hocleaf.

54 Malua crispa . simeringwyrt .

55 Polipedium . hremmes fot.

56 Consolda . dæges eage .

57 Solsequium . solsece.

58 Slarigia. slaræge.

59 Adriaca. galluc.

60 Ruta . rude.

61 Betonica . seo læsse bisceopwyrt .

62 Petrocilinum . petersylige.

63 Costa. cost.

64 Epicurium . halswyrt .

65 Millefolium . geruwe.
Parallels in $\boldsymbol{A E G r}$ and $\boldsymbol{A E G I}$

(ed. Zupitza 1880)

Letters written above the lemma

AEGI 310.8 herba gærs oððe wyrt

AEGI 310.8 allium leac

AEGI 310.8 dilla docca

il

AEGI 310.8-9 libestica lufestice

ÆEGI 310.9 febrefugia feferfugje $\quad e b r$

AEGI 310.9 simphoniaca hennebelle imf

AEGI 310.10 avadonia feltwyrt

ÆEGI 310.10 aprotanum suðerne wudu

AEGI 310.10-11 sinitia grundeswelige init

AEGI 310.11 feniculum finol

erased: $e n$ ?

ÆEGI 310.11 anetum dile

AEGI 310.11-12 electrum elehtre lec

AEGI 310.12 malua hocleaf

alu

AEGI 310.12 malua crispa simæringcwyrt

AEGI 310.12-13 polipedium hremmes fot erased: oli?

AEGI 310.13 consolda dæges eage ons

EGI 310.13-14 solsequium solsece ols

AEGI 310.14 slaregia slarege lar

AEGI 310.14 adriaca galluc dri

AEGI 310.14 ruta rude ut

ÆEGI 310.14-15 betonica seo læsse et

bisceopwyrt

AEGI 310.15 petrocilinum petersylige partly erased -

illegible

AEGI 311.1 costa cost

AEGI 311.1 epicurium halswyrt pic

AEGI 311.1 millefolium gearewe ill 
Barlow 35, fol. 57v/1-19

66 Tanicetum . helde .

67 Saxifriga . sundcorn .

68 Citsona. fanu.

69 Calamus . t canna . $t$ arundo. hreod.

70 Papauer papig.

71 Absinthium . wærmod.

72 Vrtica. netele.

73 Archangelica . blindnetele.

74 Plantago . wegbræde.

75 Quinquefolium . fifleafe.

76 Vinca , perfince.

77 Marubium . hárhune .

78 Camicula . argentilla .

79 Fraga . strewberian wisan.

80 Ciminum . cymen .

81 Modera . cicena mete.

82 Apium . merce.

83 Lappa . clate . oðde clifwyrt .

84 Helena. horselene.

85 Sandix. wad.

86 Caula. caul.

87 Cresco. cærse.

88 Mente. minta.

89 Cerpillum . fille .

90 Artemesia. mugcwyrt.

91 Saluia . saluie.

92 Fel terre . $t$. centaria . eorðgealla .

93 Ambrosia . hindheoleoð.

94 Pionia.

95 Mandragora.
Parallels in $\mathbb{A E G}$ and $\boldsymbol{A E G I}$

(ed. Zupitza 1880)

AEGI 311.1-2 tanicetum helde

AEGI 311.2 saxifriga sundcorn

ÆEGI 311.2 citsana fana

EEG 311.2-3 calamus t canna tarundo alam hreod

AEGI 311.3 papauer papig

AEGI 311.3 absinthium wermod

ÆEGI 311.4 urtica netle

AEGI 311.4 archangelica blindnetle

ÆEGI 311.4 plantago wegbræde

AEGI 311.5 quinquefolium fifleafe

AEGI 311.5 uinca perfince

AEGI 311.5 marubium harhune

ÆEGI 311.6 camicula argentille

ÆEGI 311.6 fraga streowberjan wisan

AEGI 311.6-7 ciminum cymen

ÆEGI 311.7 modera cicena mete

AEGI 311.7 apium merce

AEGI 311.7-8 lappa clate oðde clifwyrt

AEGI 311.8 helena horselene

ÆEGI 311.8 sandix wad

AEGI 311.8-9 caula t magudaris cawul

ÆEGI 311.9 cresco cærse

AEGI 311.9 menta minte

AEGI 311.9 serpillum fille

ÆEGI 311.10 artemesia mugcwyrt

AEGI 311.10 saluia saluje

AEGI 311.10-11 fel terrae t centauria eorðgealla

ÆGI 311.11 ambrosia hindheolad

ÆEGI 311.11 pionia

AEGI 311.11 mandragora

\author{
Letters written \\ above the lemma \\ ani \\ axi \\ its \\ $a p$ \\ $r t i$ \\ lant \\ uinq (partly \\ erased) \\ inc \\ arub
}

partly erased:

rag?

od (partly

erased)

pi

lap

el

and

ent

erp

alu

el

partly erased: io?

and 
Barlow 35, fol. 57v/1-19

96 Pollegia . hulwyrt .

97 Organum . organe

98 Cardux. pistel.

99 Hermodactula . crawanleac.

100 Pastinata . wealmoru.

101 Lilium . lilige .

102 Rosa. rose.

103 Viola . clæfre .

104 Agrimonia . garclife .

105 Rafanum . rædic.

106 Filex . fearn .

107 Carex. segc .

108 luncus . $t$. scirpus . rixs

109 Sabina . sauene.

110 Epiaster . merce.

111 Malagma . clipa .
Parallels in $\boldsymbol{A E G r}$ and $\boldsymbol{A E G I}$

(ed. Zupitza 1880)

AEGI 311.11-12 pollegia hylwyrt oððe

dweorge dwesle

AEGI 311.12 organum organe

AEGI 311.13 cardus pistel

ÆEGI 311.13 hermodactula $\nmid$ tidolosa

crawan leac

AEGI 311.13-14 pastinaca wealmoru

AEGI 311.14 lilium lilje

ÆEGI 311.14 rosa rose

AEGI 311.14 uiola clæfre

AEGI 311.14-15 agrimonia garclife

AEGI 311.15 rafanum rædic

AEGI 311.15 filex fearn

AEGI 311.15 carex sege

AEGI 311.16 iuncus $\downarrow$ scirpus risc

AEGI 312.9 sabina sauene

AEGr 27.8 apiaster merce; AEGI 311.7

apium merce

AEGr 33.13; AEGI 302.18 malagma cliða

Letters written
above the lemma
oll
rg
partly erased:
ard?
erm
partly erased:
ast?
lil
or
iol
af
ile
unc
ab
pia
alag

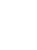


ond Barlow 35 glossary is a faithful rendition of its Ælfrician source, almost without any omission or variation in order, ${ }^{6}$ and also includes the two entries that are not glossed in ÆGl (94 Pionia 'peony' and 95 Mandragora 'mandrake'). Glossary II would therefore be of little interest, were it not for a particular palaeographic and metatextual feature. Above most of the lemmata, a later hand, of the twelfth century, rewrote some of the letters of the Latin words. These letters are mostly the second, third, and fourth letters of the lemma, with omission of initials; however, in some cases, these 'tags' extend beyond the fourth or reproduce the first, second, and third letters. It is likely that, in most cases, this later scribe felt no need to mark the initials of the lemmata because they are capitalized. The reason behind these 'tags' is not immediately clear; to my knowledge, this feature is not paralleled by any other glossary of the period. According to Liebermann (1894: 414), this intervention is aimed as a concession to later readership to facilitate reading; Ker (1957: 356) states that "[t]he script [insular letter-forms, high $e$ ligatures] offended a twelfth-century reader who put in some letters of most of the Latin lemmata on $\mathrm{f}$. $57 \mathrm{v}$ in their normal caroline forms", an explanation with which Doane (2007: 80) seems to agree. According to Faulkner (2008: 74), "graphs common to Caroline and insular minuscules (like $b$ and $l$ ) are among those transcribed, which suggests that the transliterator's main interest was in the morphology of the script. It is possible he was learning to imitate a pre-Conquest hand". The hypothesis is tempting, although this would not explain why this feature involves only specific lemmata and their initial letters. In my opinion, the later scribe of Barlow 35 may have selected some words in order to alphabetize them at a later stage; the rewriting of letters above the lemmata represents a 'tag' for a reshuffling and later ordering of the words in $A B C$-, or even $A B C D$-order. Latin-Old English alphabetical glossaries "underwent progressive refinement", and this kind of arrangement is found in a work such as the Harley Glossary, which was copied at around the same time as the glossaries in Barlow 35 and is in $A B C$-order, with "traces of attempts to arrive at an $A B C D$-order" (Lendinara 1999: 16). The hypothesis that these marks were a means to prepare alphabetization is also paralleled by the glossarial activity of the period: the Durham Glossary and the Laud Herbal Glossary are in $A$ - and $A B$-alphabetical order; they also embed material from earlier Latin-Old English glossaries (see Pheifer 1974: xxxviii-xxxix; Rusche 2003; Rusche 2008). To these parallels, one might also add that the chapter on plant names in the Brussels Glossary shows sporadic traces of alphabetization (Rusche 2003: 182).

6 As in Glossary I, there is a tendency towards simplification: see glosses 86, 96, 99, in which the glossator dropped either the second lemma or the second interpretamentum occurring in ÆGl. 
Glosses 109-111 deserve some further comment. They are essentially additions to the chapter of Nomina herbarum. Liebermann (1894: 414-415) argued that they derive from a different part of $Æ G r$ and ÆGl ("Hierauf folgen drei Glossen, die bei Ælfric an anderer Stelle stehen”). Gloss 109, Sabina : sauene, is from ÆGl, as Liebermann notes (more specifically, it is an entry from the chapter Nomina arborum); but glosses 110-111 may actually derive from ÆGl rather than from ÆGr, as suggested by Liebermann. Gloss 110, Epiaster : merce, is by all means a variant of gloss 82 Apium : merce, while gloss 111 parallels an entry of ÆGl's chapter Nomina membrorum. Most importantly, it seems that the compiler of the second glossary in Barlow 35 added these entries because they were thought to fit with the other plant names. Sabina refers to the 'savin juniper', a shrub (see BT s.v. safine). Apiaster is an 'umbelliferous plant', perhaps the melissa officinalis or lemon balm (DMLBS s.v. apiaster). A malagma (Greek $\mu \alpha \dot{\lambda} \alpha \gamma \mu \alpha)$ is an 'emollient, poultice' (DMLBS s.v. malagma ), which suggests that the compiler's interest in herbs also extended to their practical use. Notably, these additions fit with the selection of material found in other herbal glossaries. The gloss Sabina: sauine is found in the Laud Herbal Glossary, no. 1299 (Stracke 1974: 59); the same glossary also includes the entry 171 Apiaster : wude merche (Stracke 1974: 25). Apiaster : vude-merce is also in the Durham Glossary, no. 33 (von Lindheim 1941: 9). The chapter on plant names in the Brussels Glossary features the entries 305 Apium : merce and 394 Malagma : sealf (Rusche 1996: 562, 564), while the AntwerpLondon class glossary includes 1018 Apiaster : wude merce (Porter 2011a: 74).

\subsection{Glossary III (see Figure 2)}

\section{Barlow 35, fol. 57v, cols. A-F}

$\begin{array}{lll}\text { A } 112 & \text { Stragula . wæstlincg. } \\ 113 & \text { Sagum hwitel . } \\ 114 & \text { Pluuinar . pyle . } \\ 115 & \text { Turribulum . storcylle . } \\ 116 & \text { Pons . brygc . } \\ 117 & \text { Vadum . ford . } \\ \text { B } 118 & \text { Pratum . mæd . } \\ 119 & \text { Aqua .wæter . } \\ 120 & \text { Gutta . t stilla . dropa . } \\ 121 & \text { Stagnum . mere . } \\ 122 & \text { Amnis . eâ. } \\ 123 & \text { Flumen . flod . }\end{array}$

Parallels in $\mathbb{A E G r}$ and $\boldsymbol{A E G ~ ( e d . ~ Z u p i t z a ~ 1 8 8 0 ) ~}$

AEGI 314.18 stragula wæstlingc

AEGI 314.18 sagum hwitel

EEGI 314.18 puluinar pyle

ÆEGI 314.6 thuribulum storcylle

AEGI 313.3-4 pons brygc

ÆEGI 313.4 uadum ford

ÆEGI 313.4 pratum mæd

ÆEGI 313.4 aqua wæter

AEGI 313.4-5 gutta t stilla dropa

AEGI 313.5 stagnum mere

ÆEGI 313.5 amnis ea

ÆEG 313.5-6 flumen t flumenus flod 
Barlow 35, fol. 57v, cols. A-F

C 124 Ripa.stæð.

125 Litus. sǽstrand.

126 Alueus . stream.

127 Torrens . burna .

128 Riuus , riðe .

129 Fons . wyll.

130 Arena. sandceosol.

D 131 Gurges . wyl.

132 Viuarium . fiscpol.

133 Latex . burna . одде broc .

134 Stimulus gád.

135 Aculeus . sticels.

E 136 Equor. sǽ.

137 Maneo . ic wunige.

138 Cigeo . ic lapige .

139 Lugeo . ic heofige.

140 Studeo. ic gecnyrdlæce.

141 Horreo . iĉ andpracige .

142 Suadeo . iĉ tihte.

F 143 Vigeo . ic strangie.

144 Subaudis . is word.

145 Subaudio . ic underhluste.

146 Subaudis. pú underhlyst .

147 Subaudit. he underhlyst .
Parallels in AEr and AEG (ed. Zupitza 1880)

ÆEGI 313.6 ripa stæp

ÆEG 313.6 litus sæstrand

ÆGI 313.6 alueus stream

AEGI 313.6-7 torrens burna

AEGI 313.7 riuus rið

AEGI 313.7 fons wyll

ÆEGI 313.7 arena sandceosol

ÆEG 313.7-8 gurges wæl

AEGI 313.8 uiuarium fiscpol

AEGI 313.8-9 latex burna oдðe broc

AEGI 304.3 stimulus gad

ÆGI 304.3 aculeus sticels

ÆEGI 297.9 mare t aequor sæ

ÆEGr 155.17-156.1 maneo ic wunige

AEGr 156.15 cico ic gelaðige

ÆGr 156.5-6 lugeo ic heofige

ÆEr 154.5 studeo ic gecnyrdlæce

ÆEGr 212.3-4 horreo ic anðracyge

AEGr 155.5-6 suadeo ic tyhte

AEGr 154.15 uigeo ic strangige oдðе geðеo

AEGr 151.2 sVBavdis ys word

AEGr 151.2-3 subaudio ic underhlyste

AEGr 151.3 subaudis du underhlyst

AEGr 151.3-4 subaudit he underhlyst

\section{Notes on Glossary III}

As noted above, Glossary III is comprised of two main parts:

112-136 Glosses from ÆGl; four from Nomina domorum (112-115);'7 a large excerpt from Nomina arborum (116-133), which mostly includes names of elements of landscape; two entries from Nomina membrorum (134-135); and a gloss, derived

7 On stragula, see also Lendinara (1999: 57-58). 
from the opening chapter of ÆGl (136 Equor : sǽ 'sea'), ${ }^{8}$ which is thematically close to the glosses taken from Nomina arborum. All batches generally retain the order of their source and do not show any sign of re-arrangement.

137-147 A batch of verbs from ÆGr, mostly drawn from the chapter on the Latin second conjugation. This batch does not feature interpolations, except for gloss 141 Horreo : ic andpracige 'I dread [sth.]', which is a second-conjugation verb derived from the chapter on inchoative verbs, and that was not copied in its inchoative form (ÆGr 212.4 horresco ic onginne to anðracigenne 'I begin to dread [sth.]'). This, again, suggests that the glossator deliberately selected verbs on the basis of their conjugation. ${ }^{9}$ As in Glossary I, these entries are first-person singular indicative present forms. On the other hand, glosses 144-147 all refer to the three singular persons of the indicative present of subaudio, which, although technically a fourth-conjugation verb, is nevertheless taken from the same chapter as the other verbs (subaudio is mentioned as part of an example related to the second-conjugation verb docere in ÆGr 150.21-151.4). These final entries are especially notable for the interpretamenta ic underhlyste, ðu underhlyst, he underhlyst, which are loan translations of the Latin lemmata (subaudio $=s u b+$ audio : under + hlyste) and, along with the derivate form underhlystunge (151.1), are not elsewhere attested other than in $Æ G r$.

\section{Conclusions}

The evidence suggests that whoever compiled the three Ælfrician glossaries copied in Barlow 35 had selected material from $Æ G r$ and $Æ G l$ and reorganized it in thematic series. ${ }^{10}$ This is particularly evident in the case of the material derived from $Æ G r$, which was employed to build word-pairs and series of verbs mostly based on Latin conjugations. In this context, it is perhaps not surprising that the first glossary continues the series of Synonyma pseudo-Ciceronis, betraying a similar interest in verbs. Accordingly, the third glossary - which is informed by the

8 Although Liebermann (1894: 415) states that the latter is drawn from ÆGr 155.17, there is no related occurrence in the text.

9 Note that gloss 143 Vigeo : ic strangie repeats gloss 30.

10 A comparison with the variants recorded in Zupitza's apparatus does not reveal significant analogies with any of the manuscripts used in his edition, except for a few correspondences shared by Cambridge, Corpus Christi College, 449 (Zupitza's 'C') and glosses 68, 72, 78, 86, 89; and by London, British Library, Cotton Julius A.ii (Zupitza's 'J') and glosses 1, 15, 78, 86. 
same principles as the first one - also features the same layout in columns found in the Synonyma and in the first glossary. ${ }^{11}$ Furthermore, a gloss such as 14 Commoda mihi III panes : læn me preo hlafas shows that the compiler did not simply copy the glosses but sometimes reworked them (or worked on a copy where such changes were already found). This aspect is also demonstrated by the adaptation of material from ÆGr into word-pairs (for example 5 Vtinam : eala; 12 Coniunctio : gepodnys); by the simplification of entries which originally included more than one lemma or interpretamentum (for example 25 Confundo : ic gemencge; 86 Caula : caul); and by mistakes (9 Amaueritis : pa ða ge lufedan). The second glossary differs from I and III in layout and in that it is a faithful copy of its source. However, it also shows traces of re-organization - namely, the addition of three glosses to the chapter, an addition which fits with compilations of plant lists of the period. The most interesting aspect of Glossary II is perhaps the intervention of a later, twelfth-century reader who 'tagged' specific Latin lemmata by rewriting their initial letters in the space between the lines. I have suggested that these mark-ups tagged words to prepare an alphabetization in $A B C$-, or even $A B C D$ order, a hypothesis that is based on parallels with the organizational criterium of alphabetical glossaries of the period such as the Harley Glossary and the Laud and Durham herbal glossaries. However, Glossary II also shows a thematic unity with Glossary III, which includes an excerpt from the chapter on the name of trees of ÆGl. This excerpt is focused on elements of landscape. Overall, the use of material from ÆGr and ÆGl in the three Ælfrician glossaries in Barlow 35 bears witness to the interests of the glossator, who produced three brief class glossaries with a selection of Latin grammatical terms and verbs, as well as sections devoted to discrete lexica, such as plant names and elements of landscape. The twelfthcentury additions show that this selection was of interest to at least one later reader of the manuscript. ${ }^{12}$

11 I am currently working on an edition of the version of the Synonyma pseudo-Ciceronis in Barlow 35.

12 I am most thankful to Patrizia Lendinara (Università degli Studi di Palermo) for commenting on earlier drafts of this paper and suggesting improvements. I would like to show my gratitude to the Bodleian Library for providing me with reproductions of manuscript Barlow 35 and for the permission to use them in this study. 


\section{Works Cited}

Alcamesi, Filippa. 2010. “Flfric’s Interrogationes Sigewulfi in Genesin: An Educational Dialogue”. In: Rolf H. Bremmer Jr and Kees Dekker (eds.). Practice in Learning: The Transfer of Encyclopaedic Knowledge in the Early Middle Ages. Leuven: Peeters. 175-202.

[Bischoff, Bernhard]. 1997. Handschriftenarchiv Bernhard Bischoff (Bibliotheca der Monumenta Germaniae Historica, HS. Cl, C2). Ed. Arno Mentzel-Reuters, mit einem Verzeichnis der beschriebenen Handschriften von Zdenka Stoklaskova und Marcus Stumpf. Microfiche edition. Monumenta Germaniae Historica Hilfsmittel 16. Munich: MGH. Available online at 〈http://www.mgh-bibliothek.de/archiv/hs/hs_c_0001_001.htm〉.

BT $=$ Bosworth, Joseph and T. Northcote Toller (eds.). 1882-1898. An Anglo-Saxon Dictionary. Based on the Manuscript Collections of the Late Joseph Bosworth. London: Oxford University Press. Supplement by T. Northcote Toller. 1921. Oxford: Clarendon. Available online at <http://bosworth.ff.cuni.cz/>.

Buckalew, Roland E. 1978. “Leland's Transcript of AElfric’s “Glossary”. Anglo-Saxon England 7: 149-164. Repr. in Christine Franzen (ed.). 2012. Ashgate Critical Essays on Early English Lexicographers. Volume I: Old English. Farnham: Ashgate. 579-594.

Butler, Marilyn S. 1981. “An Edition of the Early Middle English Copy of $Æ$ Elfric's 'Grammar' and 'Glossary' in Worcester Cathedral MS F.174”. Unpubl. PhD dissertation, Pennsylvania State University.

Cataldi, Claudio. 2019. “Nomina membrorum in Oxford, Bodleian Library, MS Bodley 730". Journal of English and Germanic Philology 118: 468-485.

$D M L B S=$ Latham, Ronald E., David R. Howlett, and Richard K. Ashdowne (eds). 1975-2013. The Dictionary of Medieval Latin from British Sources. London: British Academy. Available online from $1 O$ ГEION at <https://logeion.uchicago.edu/>.

Doane, A. N. 2007. Grammars: Handlist of Manuscripts. Anglo-Saxon Manuscripts in Microfiche Facsimile 15. Tempe, AZ: Arizona Center for Medieval and Renaissance Studies.

Faulkner, Mark. 2008. "The Uses of Anglo-Saxon Manuscripts c. 1066-1200”. Unpubl. $\mathrm{PhD}$ dissertation, University of Oxford.

Gneuss, Helmut. 1990. "The Study of Language in Anglo-Saxon England". Bulletin of the John Rylands Library 72: 3-32.

Gneuss, Helmut and Michael Lapidge. 2014. Anglo-Saxon Manuscripts: A Bibliographical Handlist of Manuscripts and Manuscript Fragments Written or Owned in England up to 1100. Toronto/Buffalo, NY/London: University of Toronto Press.

Hill, Joyce. 2007. “Elfric’s Grammatical Triad”. In: Patrizia Lendinara, Loredana Lazzari and Maria Amalia D'Aronco (eds.). Form and Content of Instruction in Anglo-Saxon England in the Light of Contemporary Manuscript Evidence. Turnhout: Brepols. 285-308.

Hunt, Tony (ed.). 1991. Teaching and Learning Latin in Thirteenth-Century England. 3 vols. Cambridge: Brewer.

Ker, Neil R. 1957. Catalogue of Manuscripts Containing Anglo-Saxon. Oxford: Clarendon. Kleist, Aaron J. 2019. The Chronology and Canon of Alfric of Eynsham. Cambridge: Brewer.

Lazzari, Loredana. 2003. "Il Glossario latino-inglese antico nel manoscritto di Anversa e Londra ed il Glossario di Ælfric: Dipendenza diretta o derivazione comune?". Linguistica e filologia 16: 159-190.

Lendinara, Patrizia. 1999. Anglo-Saxon Glosses and Glossaries. Ashgate: Aldershot. 
Lendinara, Patrizia. 2009. “Glossari anglosassoni per argomenti: Gebrauchstexte oder nicht?”. In: Letizia Vezzosi (ed.). La letteratura tecnico-scientifica nel medioevo germanico: Fachliteratur e Gebrauchstexte. Alessandria: Edizioni dell'Orso. 119-144.

Lendinara, Patrizia. 2011. "The Scholica Graecarum glossarum and Martianus Capella”. In: Sinéad O’Sullivan and Mariken Teeuwen (eds.). Carolingian Scholarship and Martianus Capella: Ninth-Century Commentary Traditions on 'De nuptiis' in Context. Turnhout: Brepols. 301-361.

Liebermann, Felix. 1894. "Aus Aelfrics Grammatik und Glossar”. Archiv für das Studium der neueren Sprachen und Literaturen 92: 413-415.

Lindheim, Bogislav von (ed.). 1941. Das Durhamer Pflanzenglossar Lateinisch und Altenglisch. Bochum-Langendreer: Pöppinghaus.

Liuzza, Roy. 2010. Anglo-Saxon Prognostics: An Edition and Translation of Texts from London, British Library, MS Cotton Tiberius A.iii. Cambridge: Brewer.

Madan, Falconer, H. H. E. Craster and N. Denholm-Young. 1937. A Summary Catalogue of Western Manuscripts in the Bodleian Library at Oxford which have not hitherto been Catalogued in the Quarto Series: With References to the Oriental and other Manuscripts. Vol. 2.2. Oxford: Clarendon.

Menzer, Melinda. 2004. “Flfric’s English “Grammar”. Journal of English and Germanic Philology 103: 106-124.

Pagan, Heather and Annina Seiler. 2019. “Multilingual Annotations in ÆElfric’s Glossary in London, British Library, Cotton Faustina A.x: A Commented Edition”. Early Middle English 2: 13-64.

Pettit, Edward. 1999. “Anglo-Saxon Charms in Oxford, Bodleian Library MS Barlow 35”. Nottingham Medieval Studies 43: 33-46.

Pheifer, J. D. (ed.). 1974. Old English Glosses in the Épinal-Erfurt Glossary. Oxford: Oxford University Press.

Porter, David W. (ed.). 2011a. The Antwerp-London Glossaries: The Latin and Latin-Old English Vocabularies from Antwerp, Museum Plantin-Moretus 16.2 - London, British Library Add. 32246. Volume 1: Texts and Indexes. Toronto: Pontifical Institute of Mediaeval Studies.

Porter, David W. 2011b. “The Antwerp-London Glossaries and the First English School Text”. In: Patrizia Lendinara, Loredana Lazzari and Claudia Di Sciacca (eds.). Rethinking and Recontextualizing Glosses: New Perspectives in the Study of Late Anglo-Saxon Glossography. Porto: Fédération internationale des instituts d'études médiévales. 153-177.

Porter, David W. 2018. "The Antwerp-London $a$-Order Glossary and the Manuscripts of Ælfric”. In: Claudia Di Sciacca, Concetta Giliberto, Carmela Rizzo and Loredana Teresi (eds.). Studies on Late Antique and Medieval Germanic Glossography and Lexicography in Honour of Patrizia Lendinara. 2 vols. Pisa: ETS. II, 587-603.

Rusche, Philip G. 1996. "The Cleopatra Glossaries: An Edition with Commentary on the Glosses and their Sources". Unpubl. PhD dissertation, Yale University.

Rusche, Philip G. 2003. “Dioscorides' De materia medica and Late Old English Herbal Glossaries”. In: Carole P. Biggam (ed.). From Earth to Art: The Many Aspects of the Plant-World in Anglo-Saxon England. Proceedings of the First ASPNS Symposium, University of Glasgow, 5-7 April 2000. Amsterdam: Rodopi. 181-194.

Rusche, Philip G. 2008. "The Sources for Plant Names in Anglo-Saxon England and the Laud Herbal Glossary”. In: Peter Dendle and Alain Touwaide (eds.). Health and Healing from the Medieval Garden. Woodbridge: Boydell. 128-144.

Sauer, Hans and Elisabeth Kubaschewski. 2018. Planting the Seeds of Knowledge: An Inventory of Old English Plant Names. Munich: Utz. 
Stokes, Peter A. 2014. English Vernacular Minuscule from Athelred to Cnut c. 990-c. 1035. Cambridge: Brewer.

Stracke, Richard J. (ed.). 1974. The Laud Herbal Glossary. Amsterdam: Rodopi.

Zupitza, Julius (ed.). 1880. Aelfrics Grammatik und Glossar: Text und Varianten. Berlin:

Weidmannsche Buchhandlung. Repr. 2001 with a new introduction by Helmut Gneuss. Hildesheim: Weidmann. 


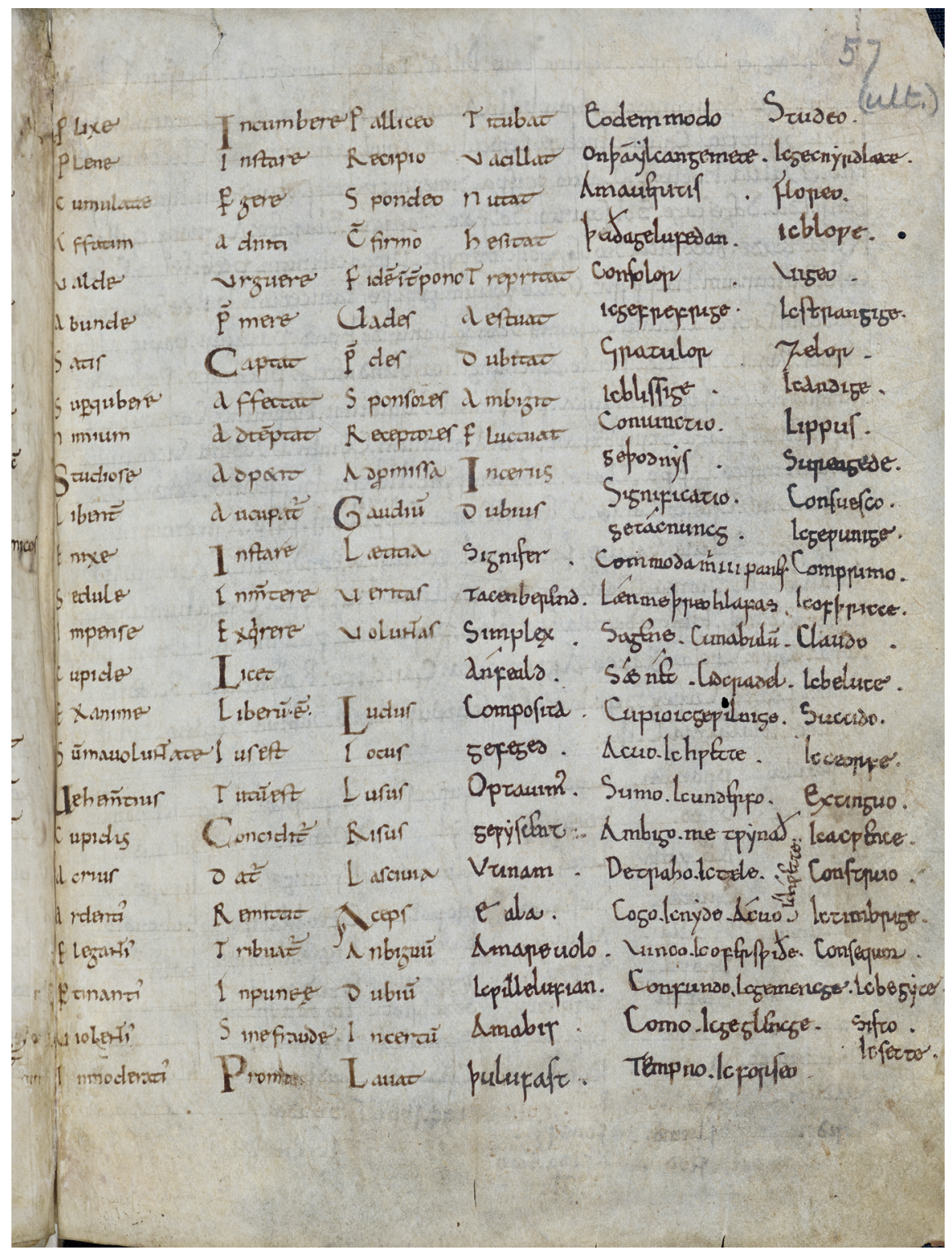

Figure 1: Oxford, Bodleian Library, Barlow 35, fol. $57 \mathrm{r}$; Glossary I begins in col. D with the first lemma "Signifer". (๑) Reproduced by permission of The Bodleian Library, University of Oxford 


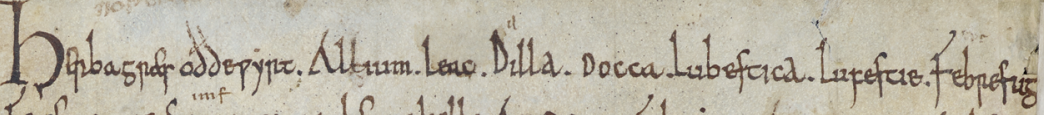

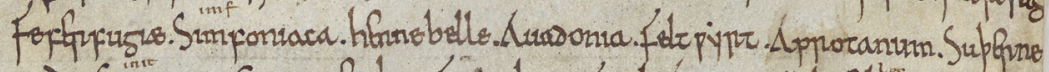

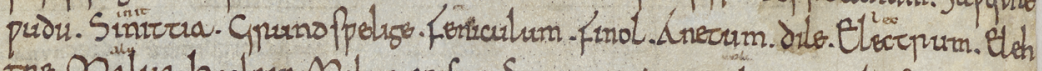

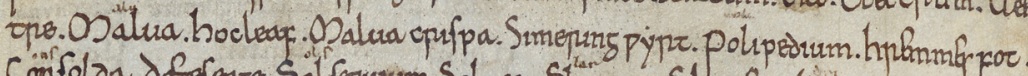

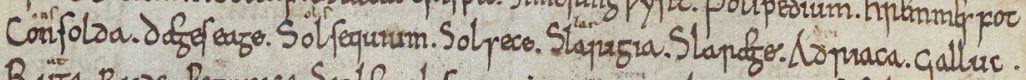

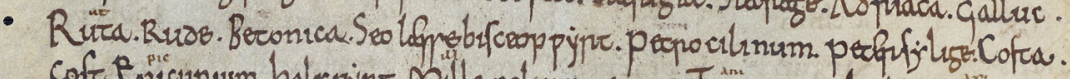

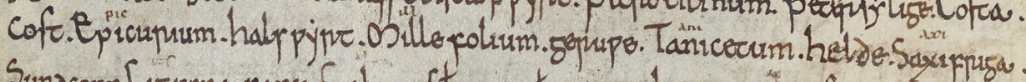

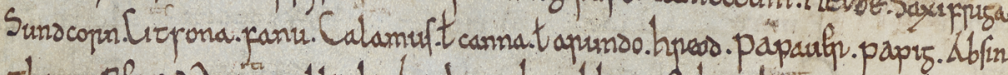

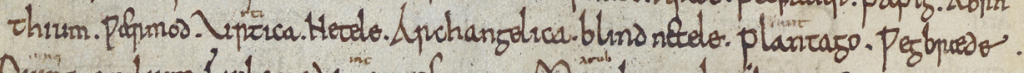

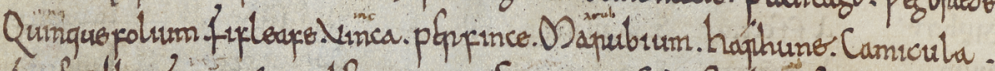

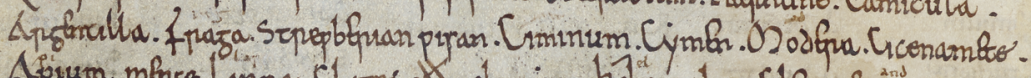

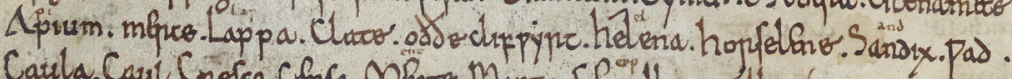

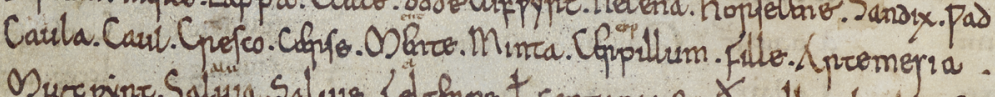

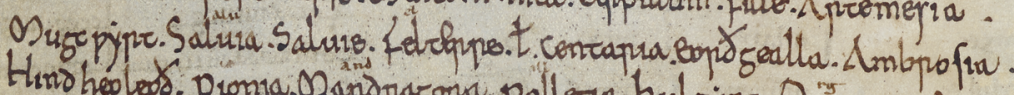

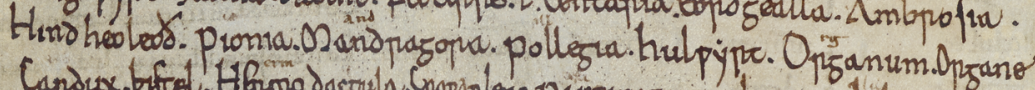

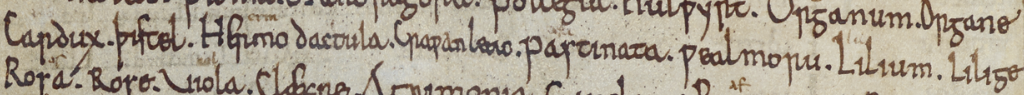

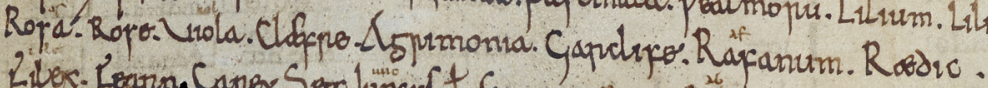

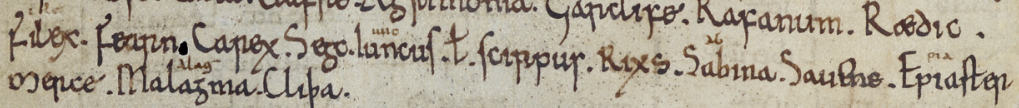
Sopuralo Pratur
poiftincs. Psers. Sed
Sazum
hpiod. Gurea.
plusunap. troila.
pile.
Dpopa.
Tupqubutur. Srasnü
stepreyllo osepos.
ponflipiyse. Ammis.
fopros.

$$
\begin{aligned}
& \text { Eâ Rutur } \\
& \text { Flamen. Fonspiylt. }
\end{aligned}
$$

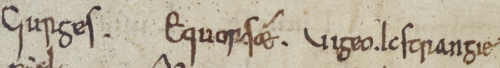 pyit. Obanzo Subuard.

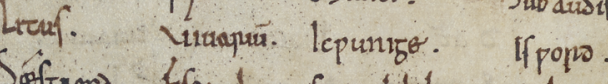

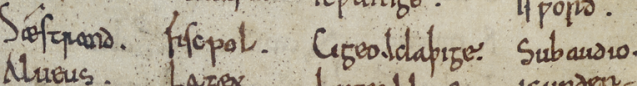

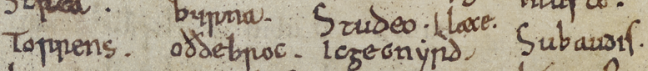

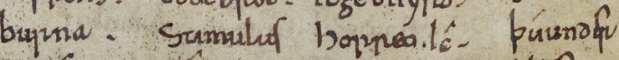

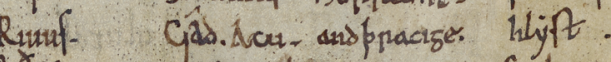 learfftrodl. Suadeo - Subaudre lociho. hly te

Figure 2: Oxford, Bodleian Library, Barlow 35, fol. 57v (C) Reproduced by permission of The Bodleian Library, University of Oxford 